\title{
Kirjallisuutta
}

\section{Tutkimus Ruotsin aikuiskoulutusuudistusten vaikutuksista}

Olofsson, Lars-Erik \& Rubenson, Kjell 1986. 1970-talets vuxenutbildningsreformer. Reflektioner kring strategier och utfall. Stockholm: Högskolan för lärarutbildning i Stockholm, Institutionen för pedagogik, Forskningsgruppen för vuxenpedagogik och återkommande utbildning. Rapport 9/1985.

Olofssonin ja Rubensonin raportti on osa laajempaa ruotsalaista tutkimusprojektia "Utvärdering av vuxenutbildningsreformerna på 1970talet" (UV-projekti), jonka tarkoituksena on kartoittaa Ruotsissa 1960-luvun lopulta lähtien toimeenpantujen koulutusuudistusten vaikutuksia ja tuloksia. Lyhyesti määriteltynä UV-projektilla pyritään selvittämään ja analysoimaan tasa-arvopoliittisista tavoitteista käsin valtiovallan noudattamaan uudistusstrategiaa, koulutukseen osallistumisen kehitystä, opetusja oppimisprosessia, koulutuksen yksilötason pitkäaikaisvaikutuksia sekä opintotukea koskevia uudistuksia.

Käsillä oleva raportti tarkastelee lähinnä aikuiskoulutukseen osallistumisessa tapahtunutta kehitystä, jota on analysoitu suhteessa valtiovallan uudistusstrategiaan sekä kyseisenä ajankohtana vallinneisiin taloudellisiin ja yhteiskunnallisiin tekijöihin. Kirjan alussa luodaan katsaus Ruotsissa viimeisimmän 20 vuoden aikana toimeenpantuihin aikuiskoulut usuudistuksiin. Tässä yhteydessä kirjoittajat analysoivat niitä ideologioita ja uudistusstrategioita, jotka ovat olleet kiinteästi yhteydes- sä uudistusten kanssa, ts. miten erilaiset yhteiskunnalliset olosuhteet ovat vaikuttaneet aikuiskoulutuspolitiikkaan ja miten tasa-arvokäsite on vaihdellut eri ajankohtina.

Olofsson \& Rubenson ovat jakaneet tarkastelun kohteena olevan ajanjakson kolmeen toisistaan erottuvaan jaksoon:

60-luvulla ruotsalaiseen aikuiskoulutukseen liittyviä suuria uudistuksia olivat kunnallisen aikuiskoulutuksen järjestäminen sekä kiinteän organisaation luominen television ja radion käytölle aikuisopetuksessa. Näiden uudistusten taustalla olivat ennen muuta sodan jälkeisen ajan koululaitoksen demokratisoitumispyrkimykset sekä inhimillisen pääoman teorian vaikutus. Kyseisten koulutusuudistusten tarkoituksena ei kuitenkaan ollut tavoittaa uusia kohderyhmiä, vaan pikemminkin vastata lisääntyneeseen kysyntään. Tässä suhteessa uudistusten taustalla ollutta tasa-arvoajattelua voidaan pitää 'elitistisenä'’.

Toisen ajanjakson muodostaa vuosien 1970-1976 välinen aika, jolloin huomio kiinnitettiin "lahjakkuusreservin", sijasta sivistyksellisesti huonoosaisiin. Mm. FÖVUX-projekti, jota pidetään hakevan toiminnan uranuurtajana, sisältyy tähän ajanjaksoon, jolloin koulutus haluttiin nähdä eräänä välineenä yhteiskunnalliselle muutokselle. Koulutuspolitiikan tärkeimpänä tavoitteena nähtiin lisätä yhteiskunnallista tasa-arvoa, jolloin käsitys tasa-arvosta muuttui elitistisestä "radikaaliksi"'.
Ajanjakson koulutusuudistuksia kuvastaa pyrkimys luoda koulutushalukkuutta niissä väestöryhmissä, jotka eivät olleet motivoituneita opiskeluun, ja tällä tavoin vahvistaa heidän resurssejaan. Käytännössä tähän pyrittiin $\mathrm{mm}$. opintoesteitä alentamalla, kohdennetulla rekrytoinnilla sekä voimakkaalla opintososiaalisen tuen kehittämisellä.

Kolmanneksi ajanjaksoksi kirjoittajat ovat määritelleet vuosien 1976-1982 välisen ajan, jota kuvastaa tasa-arvopoliittisten päämäärien asteittainen heikentyminen, mikä heijastui mm. vähentyneissä määrärahoissa. Tämän taustalla kirjoittajat näkevät ennen kaikkea hallitusvallan siirtymisen oikeistopuolueille sekä valtiontalouden voimakkaan heikentymisen. Tässä yhteydessä on kuitenkin huomattava, ettei virallisissa kannanotoissa ollut silti havaittavissa varsinaista muutosta koulutuspoliittisissa tavoitteissa.

Tutkimuksen empiirisenä aineistona on käytetty Ruotsin valtion virallisia tilastoja, joita Statistiska Centralbyrån julkaisee vuosittain. Näiden lisäksi kirjoittajat ovat käyttäneet hyväkseen nk. ULF-tilastoja, joita he ovat jossain määrin muokanneet tätä tutkimusta varten. Näiden tilastojen avulla on aluksi tarkasteltu ko. ajanjaksona vallinnutta yleistä taloudellista kehitystä, jonka jälkeen kirjoittajat siirtyvät tarkastelemaan aikuiskoulutukselle myönnettyjen määrärahojen kehitystä. Tätä on arvioitu sekä koulutuksen eri järjestäjien kesken että myös suhteessa koko 
koulutusjärjestelmän rahoitukseen. Keskeisenä havaintona on se, että aikuiskoulutus oli Ruotsissa erittäin suosiollisessa asemassa koko 1970-luvun, jonka jälkeen tapahtui selvää taantumista suhteessa koulujärjestelmään. Tasa-arvopoliittisesta näkökulmasta on kiintoisaa havaita, että kohdennettujen määrärahojen osuus aikuiskoulutukselle myönnetyistä kokonaismäärärahoista kasvoi koko ajan 80-luvulle tultaessa, jonka jälkeen sen osuus pysähtyi n. $30 \%$ :n paikkeille.

Kirjan viidennessä luvussa tarkastellaan aiemmin mainittujen tilastojen pohjalta koulutusuudistusten vaikutuksia osallistujien määriin ja rakenteisiin. Huomio on tällöin kiinnitetty erityisesti sivistyksellisesti huono-osaisiin, joiden tulisi tasa-arvotavoitteiden mukaan olla yliedustettuina aikaisemman vähäisen koulutuksen johdosta.

Kirjoittajat ovat jakaneet osallistumista koskevan analyysinsa kahteen osaan, joista ensimmäisenä tarkastellaan osallistumisessa tapahtunutta kehitystä kokonaisuutena suhteessa koulutuksen eri järjestäjien kesken. Tämän jälkeen analysoidaan osallistujarakenteita, jossa yhteydessä kirjoittajat kiinnittivät erityisen huomion niihin ryhmiin, joita perinteisesti on pidetty huono-osaisina. Tarkastelun kohteina olleista ryhmistä (naiset, puutteellisen peruskoulutuksen omaavat, "työläiset", osa-aikatyöläiset, kotonaan työskentelevät sekä maaseudun asukkaat) ainoastaan naisten kohdalla koulutukseen osallistuminen on osoittanut tasa-arvon kannalta myönteisiä tuloksia.

Entä miten koulutusuudistukset ovat sitten onnistuneet? Tähän kysymykseen kirjoittajat vastaavat kolmesta eri näkökulmasta:

Ensinnäkin he tarkastelevat ruotsalaisten aikuiskoulutukseen osallistumista kansainvälisestä näkökulmasta vertaile- malla osallistujamäärien kehitystä Norjan ja Kanadan vastaaviin. Vertailusta käy selvästi ilmi, että ruotsalaiset ovat osallistuneet norjalaisia ja kanadalaisia huomattavasti enemmän aikuiskoulutukseen.

Toiseksi kirjoittajat tarkastelevat osallistumista suhteessa valittuihin strategioihin. Tällöin tärkeimmäksi kysymykseksi nousee juuri koulutuksellisen tasa-arvon kehitys, josta he toteavat, ettei mitään merkittävää muutosta ole ollut havaittavissa suuntaan eikä toiseen.

Kolmantena näkökulmana Olofsson \& Rubenson tarkastelevat valtion mahdollisuuksia vaikuttaa aikuiskou- lutuksen kehitykseen. Heidän mukaansa 1960-70 -lukujen koulutusoptimismin vuosista, jolloin uskottiin, että koulutuksen avulla pystytään muuttamaan yhteiskuntaa tasa-arvoisempaan ja demokraattisempaan suuntaan, on tultu tilanteeseen, jossa valtiovallan mahdollisuudet suoraan ohjata aikuiskoulutusta ovat vähentyneet. Tässä yhteydessä kirjoittajat tuovat esille voimakkaasti lisääntyneen työelämän koulutuksen, jonka kehittämistä ohjaavat enemmän tuotannon tehostamiseen ja taloudelliseen hyötyyn liittyvät kuin tasa-arvopoliittiset näkökohdat.

Arto Juhela 